\title{
Bacteriophage D: an IncD Group Plasmid-specific Phage
}

\author{
By J. N. COETZEE, ${ }^{1 *}$ D. E. BRADLEY, ${ }^{2}$ G. LECATSAS,${ }^{3}$ \\ LAUREEN DU TOIT ${ }^{1}$ AND R. W. HEDGES ${ }^{4}$ \\ ${ }^{1}$ Department of Medical Microbiology, University of Pretoria and Bacterial Genetics Research \\ Unit of the South African Medical Research Council, PO Box 2034, Pretoria 0001, South Africa \\ ${ }^{2}$ Faculty of Medicine, Memorial University of Newfoundland, St John's, \\ Newfoundland AlB 3V6, Canada \\ ${ }^{3}$ Department of Virology, University of Pretoria, PO Box 2034, Pretoria 0001, South Africa \\ ${ }^{4}$ Plant Genetic Systems, J. Plateaustraat 22, B-9000, Gent, Belgium
}

(Received 15 May 1985; revised 9 July 1985)

\begin{abstract}
The existence of the plasmid incompatibility group $\mathrm{D}$ was reaffirmed as a result of compatibility experiments done on plasmids R687, R711 b, R778b and R840 which were previously tentatively accepted as constituting the group. The group was further delineated by the isolation of a phage, phage D, which adsorbed specifically to IncD plasmid- encoded pili produced by Escherichia coli K12 strains and strains of Salmonella typhimurium, Proteus morganii and Klebsiella oxytoca harbouring one of these plasmids. Plaque formation, like that of phage pil $\mathrm{H} \alpha$, was temperature sensitive in that plaques formed at $26^{\circ} \mathrm{C}$ but not at $37^{\circ} \mathrm{C}$. Plaques were fairly clear, regular in outline and varied from pinpoint to about $1.5 \mathrm{~mm}$ in diameter on $E$. coli hosts where plaques were detected, but on the other hosts the plaques were more turbid and often irregular in outline. The phage did not plate (or propagate) on IncD plasmid-carrying strains of Providencia alcalifaciens, Providencia stuartii or Serratia marcescens. The phage had an isometric hexagonal outline with a diameter of about $27 \mathrm{~nm}$. It contained RNA and resembled two other RNAcontaining phages, $\mathrm{M}$ and pilH $\alpha$, by being sensitive to chloroform. It adsorbed to the sides of the very distal ends of the shafts of IncD plasmid-coded pili.
\end{abstract}

\section{INTRODUCTION}

The plasmid incompatibility (Inc) group D has not been formally described. Datta (1979) mentioned it for the first time merely as an unpublished observation.

Plasmids R687, R711b, R778b and R840, which now constitute the group, were present in strains of Providencia (Hedges, 1974). On the basis of incompatibility reactions, R711 b and $\mathrm{R} 778 \mathrm{~b}$ were at the time assigned to the IncX plasmid group. Plasmids R687 and R840 were members of a group of 15 plasmids which all coded for resistance to ampicillin and kanamycin but were heterogenous in other respects. Lack of suitable markers limited incompatibility tests and these two plasmids, as well as a number of others, were not allocated to particular incompatibility groups although the suggestion was made that the collection could represent several undescribed groups. By 1977 (Bradley, 1977) there was some doubt about the classification of $\mathrm{R} 711 \mathrm{~b}$ and $\mathrm{R} 778 \mathrm{~b}$ as experiments had indicated that $\mathrm{R} 711 \mathrm{~b}$ and the IncX plasmid R6K were not incompatible.

Bradley (1977) found that pili produced by plasmids R711b and R778b were serologically related. These pili resembled those produced by $\mathrm{IncFI}$ and $\mathrm{F}_{0} l a c$ plasmids morphologically (thick, flexible) but differed serologically from pili specified by the latter plasmids. He also determined that although the RNA-containing phage R17 adsorbed to the shafts of only the IncFI pili, the filamentous phage fd adsorbed to the tips of all the above pili and lysed the corresponding Escherichia coli host strains. 
Bradley \& Meynell (1978) failed to propagate phage MS2 on strains of $E$. coli carrying plasmid R711b. In electron microscopic specimens of these bacteria exposed to high concentrations of the phage and fixed with formalin, they demonstrated adsorption of phage MS2 along the entire length of R711b-coded pili. Without this fixation the pili did not show adsorbed virions. They concluded that adsorption of phage MS2 to R711b pili was a reversible event not leading to any significant level of infection, as no plaques were found, and that formalin apparently stabilized the adsorption.

Bradley (1980) listed the plasmids R711b and R778b as belonging to Inc group D and demonstrated a serological relationship between pili determined by the then unclassified plasmid R687 and those encoded by R711b. Subsequently Sirgel et al. (1981) and Bradley et al. (1982) added plasmids R840 and R687 respectively to the IncD group on the grounds of unpublished experiments of R. W. Hedges.

Phage $\mathrm{J}$ (Bradley et al., 1982), apart from plating (or propagating) on $\mathrm{IncJ}$ and some IncC plasmid-carrying strains of $E$. coli, also plated on strains of the latter organisms harbouring any of the IncD plasmids. This DNA-containing phage which resembles phage T3 (Bradley, 1967) but is significantly smaller, adsorbed to the shafts of the pili coded for by these plasmids. The lysis observed served to confirm the phage fd plating experiments and morphological findings (Bradley, 1977, 1980) on strains carrying R711b, R778b and R687, that all these plasmids synthesized pili constitutively.

To help in classifying the as yet poorly described IncD group, it was decided to investigate the incompatibility arrangement of the four plasmids mentioned above. Also in order to have a rapid means of identifying bacteria harbouring these plasmids, we attempted the isolation of a phage from sewage, specifically lytic for these strains. Since the plasmids code for constitutive production of pili (see above) this was considered to be a feasible proposition (Meynell et al., 1968; Meynell \& Lawn, 1968). Here properties of such an RNA-containing phage are described.

\section{METHODS}

Bacteria, bacteriophages and plasmids. Bacteria and bacteriophages are listed in Table 1. Species identification of the original IncD plasmid-harbouring Providencia strains was not made (Hedges, 1974) and the strains are no longer available. Plasmids used for incompatibility testing and host range experiments originated from the collection of Naomi Datta (Datta, 1977, 1979). Apart from plasmids belonging to the IncD incompatibility group (Tables 2 and 3), only some of those which encoded constitutive pilus synthesis (as judged by plaque formation by appropriate plasmid-specific phages) were used in host range experiments (Coetzee et al., 1985). Thus one or more plasmids belonging to the following Inc groups were used: C (Sirgel et al., 1981), F subgroups I-IV (Jacob et al., 1977), HI and HII (Coetzee et al., 1985), $\mathrm{I}_{1}$ and $\mathrm{I}_{2}$ (Coetzee et al., 1982), J (Bradley et al., 1982), M (Coetzee et al., 1983), N, P and W (Coetzee et al., 1979), X (Bradley et al., 1981 b), and plasmid EDP208 ( $\mathrm{F}_{0}$ lac drd) (Bradley et al., $1981 a$ ). Plasmid-carrying strains were maintained on selective antibacterial drug-containing media to minimize plasmid segregation (Bradley, 1977).

Media, antibacterial agents, general phage techniques, transfer of plasmids by conjugation, organic solvent and RNAase sensitivity of phage, temperature sensitivity of plaque formation and production of phage lysates by a soft agar layer technique. These were as described and referred to by Adams (1950), Coetzee et al. (1979, 1985), Bradley et al. $(1980,1981 b)$, Ackermann et al. (1978) and Hershey et al. (1943). The minimal glucose agar was as described in Clowes \& Hayes (1968). As all IncD plasmids are unstable in E. coli and in Salmonella typhimurium strains (see Results; Bradley, 1977), the broth and soft top-layer agar used in experiments with these plasmid-carrying strains contained appropriate plasmid-selective antibacterial agents. Phage isolation experiments and all other experiments were done at an incubation temperature of $26^{\circ} \mathrm{C}$ unless otherwise stated. This was done to avoid the initial confusion resulting from the isolation of the temperature-sensitive phage pil $\mathrm{H} \alpha$ using a temperature of $37^{\circ} \mathrm{C}$ (Coetzee et al., 1985). The $26^{\circ} \mathrm{C}$ incubation temperature was considered appropriate in view of the fact that the non-temperature sensitive RNA-containing phages C-1 (Sirgel et al., 1981) and M (Coetzee et al., 1983) plated on their respective hosts at the latter temperature (J. N. Coetzee, unpublished).

Classification of plasmids by incompatibility. This was based on the principles outlined by Datta (1979) using the methods of Coetzee et al. (1972). Briefly, $\mathrm{R}^{+}$E. coli cultures were grown in media selective for the plasmid carried, washed three times in drug-free broth and then allowed to conjugate for $4 \mathrm{~h}$ in that medium. Mating mixtures were plated on medium selective for transconjugants and on non-selective medium to provide colonies in which retention of the resident plasmid could be determined. All crosses were done at least three times.

Phage isolation. Preliminary experiments had indicated that phage fd only plated on $E$. coli $\mathrm{K} 12$ strains carrying the plasmids R687, R711b, R778b and R840. The phage did not plate on S. typhimurium M827-2 or Providencia 
Table 1. Bacteria and bacteriophages

Bacteria

Escherichia coli $\mathrm{K} 12$

J53

J53-2

J62

J62-1
Properties*

\author{
Pro- $^{-}$Met $^{-}(\lambda)$ \\ Pro $^{-}$Met $^{-}$Rif $^{\mathrm{R}}(\lambda)$ \\ $\mathrm{Lac}^{-} \mathrm{Pro}^{-} \mathrm{His}^{-} \mathrm{Trp}^{-}(\lambda)$ \\ $\mathrm{Lac}^{-}$Pro $^{-} \mathrm{His}^{-} \mathrm{Trp}^{-} \mathrm{Nal}^{\mathrm{R}}(\lambda)$
}

Salmonella typhimurium LT2trpA8-1

Serratia marcescens

SM89-1

Spontaneous $\mathrm{Nal}^{\mathrm{R}}$ mutant of the tryptophan $\mathrm{A}$ auxotroph of LT2

Spontaneous $\mathrm{Nal}^{\mathrm{R}}$ mutant of SM89

Klebsiella oxytoca

G147

Proteus morgani

$2815 \mathrm{nal}-\mathrm{r}$

2815-2

Spontaneous Rif ${ }^{\mathrm{R}}$ mutant of 2815

Providencia alcalifaciens

P29nal-r

P29-2

Providencia stuartii

NCTC 9297-2

Bacteriophages

fd

$\mathrm{F}_{0} l a c$

J

M

MS2

$\mathbf{t}$

Spontaneous Rif ${ }^{\mathrm{R}}$ mutant of P29

Spontaneous $\mathrm{Nal}^{\mathrm{R}}$ mutant of NCTC 9297

Filamentous phage adsorbing to tips of $\mathrm{IncF}$ subgroups I-IV, IncD and $F_{0}$ lac plasmid-coded pili

RNA-containing phage adsorbing only to the sides of the distal ends of shafts of $F_{0} l a c$ plasmid-coded pili

Resembles phage $\mathrm{T} 3$ but is significantly smaller.

DNA-containing and adsorbs to shafts of IncJ,

$C$ and D plasmid-coded pili

RNA-containing phage adsorbing uniformly to the sides of shafts of IncM-coded pili. Sensitive to chloroform

RNA-containing phage adsorbing uniformly along the sides of shafts of IncF subgroups I-IV plasmid-coded pili. The phage was also shown to adsorb to sides of IncD-coded pili in formalinfixed preparations but does not form plaques on strains carrying IncD plasmids

RNA-containing phage of adsorbing uniformly to the sides of shafts of IncHI and IncHII-coded pili. Sensitive to chloroform and temperaturesensitive for plaque formation

RNA-containing phage adsorbing only to the sides of the distal ends of shafts of IncT-coded pili
Reference

Bachmann (1972)

Datta et al. (1980)

Coetzee et al. (1979); J. N.

Coetzee (unpublished)

Bradley et al. (1982)

Coetzee et al. (1983)

Coetzee (1966); Coetzee et al (1966)

J. N. Coetzee (unpublished)

Coetzee et al. (1966); Coetzee \&

Kruger (1980)

J. N. Coetzee (unpublished)

Coetzee (1963)

Marvin \& Hoffmann-Berling (1963); Bradley (1977)

Bradley et al. (1981a)

Bradley (1967); Bradley et al. (1982)

Coetzee et al. (1983)

Davis et al. (1961); Bradley \&

Meynell (1978)

Coetzee et al. (1985)

Bradley et al. (1981c) ${ }^{*}$ Abbreviations: $\mathrm{Lac}^{-}$, inability to use lactose as carbon source; $\lambda$, lysogenic for phage lambda; $\mathrm{Nal}^{\mathrm{R}}$,
resistant to nalidixic acid; Rif ${ }^{\mathrm{R}}$, resistant to rifampicin.

alcalifaciens $\mathrm{P} 29$ nal-r harbouring these plasmids. This possibly meant that the corresponding pili were not being properly expressed by these strains (see Results). These results ruled out the advantageous selective plating method devised by Meynell \& Lawn (1968). Sewage samples (obtained from various sewage works in the PretoriaJohannesburg area) were accordingly simply enriched with one of the IncD plasmid-bearing $E$. coli strains (Bradley et al., 1981 b) in the presence of $20 \mu \mathrm{g}$ nalidixic acid $\mathrm{ml}^{-1}$ to inhibit DNA-containing phages (Watanabe \& August, 1967). After overnight incubation the enriched sewage filtrates were spotted on lawns of the same strain used for enrichment, growing on nutrient agar and on this agar containing $25 \mu \mathrm{g} \mathrm{RNAase} \mathrm{ml}{ }^{-1}$ (BDH). Filtrates 
were also spotted on growing lawns of the isogenic strains lacking the particular plasmid and incubated overnight. By noting the sensitivity of prospective plasmid-specific phage to RNAase, this approach excluded the unnecessary re-isolation of broad host range DNA-containing filamentous phages.

Concentration of phage. Final concentrations of polyethylene glycol (mol. wt 6000$)$ of $8 \%(\mathrm{w} / \mathrm{v})$ (Bradley et al., $1981 \mathrm{c}$ ), $10 \%$ (Bradley et al., $1981 \mathrm{a}$ ) and $11 \%$ (Coetzee et al., 1985) with $0.5 \mathrm{M}-\mathrm{NaCl}$ were assessed (not shown) for concentrating phage D (see Results) by the method of Yamamoto et al. (1970). The optimal concentration proved to be $11 \%(\mathrm{w} / \mathrm{v})$. Pellets were finally suspended in small volumes of distilled water.

Bacteriophage propagation. The method was that of Coetzee et al. (1985) using phage D (see Results).

Preparation of phage antiserum. Eight injections $\left(1.0 \mathrm{ml}, 1 \times 10^{10}\right.$ p.f.u. $\left.\mathrm{ml}^{-1}\right)$ of phage D.J53(R778b) (see Results) were given intravenously at $3 \mathrm{~d}$ intervals to two rabbits. After resting the animals for $15 \mathrm{~d}$, blood was collected and the serum was heated at $56^{\circ} \mathrm{C}$ for $30 \mathrm{~min}$ to inactivate complement. The serum was then absorbed with strain J53(R778b) to remove somatic, flagellar and pili antibodies.

Electron microscopy. A large loopful of J53-2(R711b) from an overnight culture on solid medium was thoroughly mixed with a $0 \cdot 1 \mathrm{ml}$ sample of phage $\mathrm{D}$ in broth (titre $1 \times 10^{9}$ p.f.u. $\mathrm{ml}^{-1}$ ). Suspensions of bacteria from such cultures yielded many detached pili (Bradley et al., 1981 c). After incubation at $26^{\circ} \mathrm{C}$ for $30 \mathrm{~min}$, a carbon-coated electron microscope specimen support grid was touched on the surface. Excess bacteria were removed by dabbing the grid on the surface of a $0.1 \mathrm{M}$-ammonium acetate solution. Negative staining was with a mixture of equal volumes of $0 \cdot 1 \mathrm{M}$-ammonium acetate and $2 \%(\mathrm{w} / \mathrm{v})$ sodium phosphotungstate solutions $(\mathrm{pH} 7 \cdot 4)$.

\section{RESULTS}

\section{Transfer of plasmids by conjugation}

Plasmids R687, R711b, R778b and R840 transferred by intraspecific surface mating in E. coli at frequencies of $3 \times 10^{-3}$ per donor $\mathrm{h}^{-1}$. This is a frequency about four times higher than that reported for $\mathrm{R} 711 \mathrm{~b}$ by Bradley et al. (1980). The plasmids transferred from the $E$. coli hosts to the Salmonella, Providencia, Proteus, Klebsiella and Serratia hosts at frequencies of about $1 \times 10^{-5}$ per donor $\mathrm{h}^{-1}$. The plasmids transferred intraspecifically between strains of Proteus morganii or Providencia alcalifaciens (Table 1) at frequencies of about $1 \times 10^{-3}$ per donor $\mathrm{h}^{-1}$ (not shown). These results may be taken to mean that, while restriction possibly limited intergenus transfer of the plasmids, intraspecies transfer proceeded at levels which could be indicative of constitutive pilus synthesis (Coetzee et al., 1983).

\section{Incompatibility grouping of plasmids}

Overnight cultures of strains of $E$. coli or $S$. typhimurium carrying plasmids R687, R711b, $\mathrm{R} 778 \mathrm{~b}$ or R840 in drug-free broth usually contained $>50 \%$ clone-forming cells that were drugsensitive whereas similar cultures of strains of Providencia alcalifaciens or Providencia stuartii yielded $>99 \%$ of drug-resistant clones (not shown). This instability of the plasmid in strains of $E$. coli complicated the determination of plasmid incompatibility specificities as strains of the latter organism were the only hosts used for these tests. The presence of kanamycin in the medium ensured that $E$. coli strains carrying plasmids $\mathrm{R} 687, \mathrm{R} 711 \mathrm{~b}$ or $\mathrm{R} 840$ were purely $\mathrm{R}^{+}$. However, $6 \mathrm{~h}$ cultures of strains carrying plasmid $\mathrm{R} 778 \mathrm{~b}$ in the presence of sulphonamide had about $60 \%$ of clones sensitive to this bacteriostatic (Gale et al., 1972) drug that had presumably lost plasmid R788b. For this reason R778b was used in donor strains and not in recipient strains as testing for displacement of this unstable plasmid in a resident capacity would be unreliable (see Methods and Table 2).

No clone composed of cells resistant to both sulphonamide and kanamycin was ever observed in the only crosses possible under the above limitations (Table 2 and not shown) and it was concluded that the plasmids were incompatible with one another. The plasmids were however compatible with representatives of all other incompatibility groups (not shown), including IncX plasmids with which some were incorrectly described as being incompatible (Hedges, 1974). On these grounds the four plasmids were allocated to the $\mathrm{D}$ incompatibility group, an arrangement which previously had only been tentatively accepted. 
Table 2. Incompatibility of plasmids $R 687, R 711 \mathrm{~b}, R 778 \mathrm{~b}$ and $R 840$

Incompatibility experiments were done as referred to in Methods. Plasmid R687 determined resistance to ampicillin and kanamycin, R711 b to kanamycin, R778b to sulphadimidine and R840 to ampicillin and kanamycin. Colonies were isolated on minimal glucose medium supplemented with proline, histidine and tryptophan, either drug-free to allow growth of the J62 strain or containing $100 \mu \mathrm{g}$ sulphadimidine (Sul) $\mathrm{ml}^{-1}$ to select for transconjugants carrying $\mathbf{R} 778 \mathrm{~b}$. Kan ${ }^{\mathrm{R}}$, kanamycin resistant; $\mathrm{Kan}$, kanamycin sensitive.

$\begin{array}{cllcr}\begin{array}{c}\text { Donor } \\ \text { strain }\end{array} & \begin{array}{c}\text { Recipient } \\ \text { strain }\end{array} & \begin{array}{l}\text { Isolation } \\ \text { medium }\end{array} & \overbrace{\text { Kan }}^{\text {No. of colonies }} & \text { Kan }^{\text {S }} \\ \text { J53-2(R778b) } & \text { J62(R711b) } & + \text { Sul } & 0 & 20 \\ \text { J53-2(R778b) } & \text { J62(R711b) } & \text { Drug-free } & 17 & 3 \\ \text { J53-2(R778b) } & \text { J62(R687) } & + \text { Sul } & 0 & 20 \\ \text { J53-2(R778b) } & \text { J62(R687) } & \text { Drug-free } & 15 & 5 \\ \text { J53-2(R778b) } & \text { J62(R840) } & \text { + Sul } & 0 & 20 \\ \text { J53-2(R778b) } & \text { J62(R840) } & \text { Drug-free } & 18 & 2\end{array}$

\section{Isolation of a $J 53(R 778 b)$-dependent bacteriophage}

From the tenth sample of sewage enriched with strain J53(R778b) a phage was isolated which plated on the above strain but neither on this strain growing in the presence of RNAase nor on a culture of $J 53$. The phage was named phage $D$ and was routinely propagated on J53(R778b).

\section{Properties of phage $D$}

Plaque formation and morphology. Phage $\mathrm{D}$ was isolated (see Methods) by using an incubation temperature of $26^{\circ} \mathrm{C}$. Temperature sensitivity tests revealed that plaque formation by phage $\mathrm{D}$ proceeded on the IncD plasmid-carrying strains of $E$. coli, S. typhimurium, K. oxytoca and Proteus morganii at temperatures up to only $32{ }^{\circ} \mathrm{C}$ (not shown). Phage fd plated on the same $E$. coli strains at temperatures of at least $37^{\circ} \mathrm{C}$ (not shown). A temperature of $26^{\circ} \mathrm{C}$ was then adopted for all other experiments with phage D. Plaques on lawns of $E$. coli which had been incubated overnight were fairly clear, regular in outline and varied from about $1.5 \mathrm{~mm}$ in diameter to pinpoint. On all other hosts on which the phage plated, plaques were more turbid and many of the larger plaques were irregular in outline. This could imply that phage adsorption sites were not as freely available as on the E. coli strains (Meynell, 1978).

Phage morphology and adsorption site. P.hage D had the semi-transparent appearance and isometric hexagonal outline (Fig. 1 c) typical of RNA-containing phages (Coetzee et al., 1985). It has a diameter of about $27 \mathrm{~nm}$. Preliminary experiments indicated that phage $\mathrm{D}$ adsorbed to pili in small numbers only. Therefore adsorption was demonstrated using a mixture of virions with an excess of $D$ pili so that there were relatively few unadsorbed phage particles. This method revealed that the virions adsorbed only to the sides of one of the ends of pilus shafts either singly (Fig. $1 a$ ) or in pairs (Fig. $1 b$ ). Adsorption was to the distal tapered end of the pilus (Fig. $1 a$ ) (Bradley et al., 1981 c). A distal adsorption site on the pilus was also found for the RNAcontaining phages $\mathrm{t}$ (Bradley et al., 1981 c) and $\mathrm{F}_{0}$ lac (Bradley et al., 1981a).

Sensitivity to organic solvents or RNAase. The plaque-forming titre of a phage D suspension was reduced by about $75 \%$ as a result of chloroform treatment, whereas the titre of phage MS2 was unaffected. The titre of phage fd was reduced by more than $99 \%$ following similar exposure. Titres of phage $\mathrm{D}$ and the latter two phages were not reduced by diethyl ether treatment. Plaque formation by D and MS2 was totally inhibited by RNAase whereas that of phage $\mathrm{fd}$ was unaffected.

Host range. Although all the plasmids encoded constitutive synthesis of sex pili in particular hosts (see Introduction and Methods), phage D only lysed strains of E. coli, S. typhimurium, $K$. oxytoca and Proteus morganii carrying IncD plasmids (not shown and Table 3). It did not plate or propagate on the Providencia or the Serratia strains carrying IncD plasmids. Also the plating activity of phages fd and $\mathbf{J}$, on IncD carrying strains, was limited to $E$. coli hosts (Table 3 ). Phage 

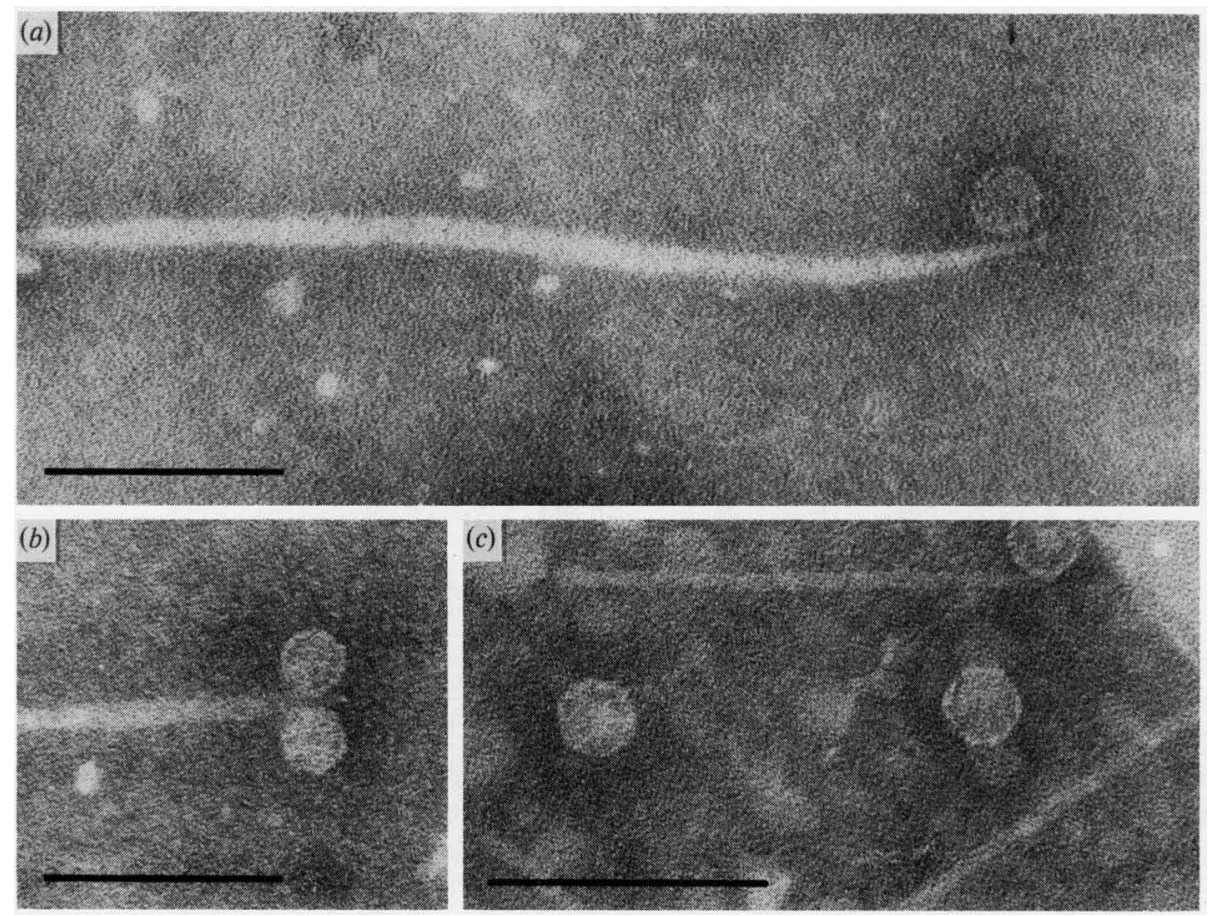

Fig. 1. Phage D virions adsorbed to IncD pili synthesized by strain J53-2(R711b). (a) Single virion adsorbed near tapered pilus tip. (b) Two virions adsorbed near pilus tip. (c) Two loose-lying virions showing hexagonal isometric outline. Bar markers, $100 \mathrm{~nm}$.

D did not plate or propagate on strains of $E$. coli carrying plasmids belonging to Inc groups $\mathrm{C}, \mathrm{F}$ subgroups I-IV, HI and HII, $\mathrm{I}_{1}$ and $\mathrm{I}_{2}, \mathrm{~J}, \mathrm{M}, \mathrm{N}, \mathrm{P}, \mathrm{W}, \mathrm{X}$ or EDP208. It thus differed in specificity from phages MS2, fd, $F_{0} l a c$ and $J$. Plating results (Table 3) of the latter two phages confirmed previous results (Bradley et al., 1981a, 1982).

Serology. Two rabbit sera raised against phage D. J53(R778b) had homologous $K$ values of 280 and $320 \mathrm{~min}^{-1}$ respectively. The sera (used in dilutions of $1: 100$ and $1: 50$ ) had no neutralizing activity $(K=0)$ against phages MS2, t, $\mathrm{F}_{0} l a c, \mathrm{M}$ or pilH $\alpha$. Apart from containing RNA these phages have one or other property similar to phage D (Table 1).

\section{DISCUSSION}

The compatibility properties of the four plasmids investigated (see Results) reaffirmed the existence of the previously poorly described incompatibility group D (see Introduction). These plasmids originated in Providencia isolates from patients in hospitals of four cities in England and Canada (Hedges, 1974) whilst none have been reported in natural isolates of any other bacterial species. In that genus they appear to be inherited stably (see Results) but when transferred to strains of $E$. coli or $S$. typhimurium their instability is so marked as to suggest that their replication (or partition) mechanisms are unable to function efficiently in the alien hosts.

The host range of phage D serves to delineate strains of $E$. coli bearing plasmids R687, R711b, $\mathrm{R} 788 \mathrm{~b}$ or $\mathrm{R} 840$ as a group from those of IncF subgroups I-IV, $\mathrm{F}_{0}$ lac, IncC and $\mathbf{J}$ plasmids, carried by the same hosts. All these plasmids code for thick flexible pili (Bradley, 1977, 1980). The host range thus confirms results of incompatibility experiments mentioned above.

It was not entirely unexpected that phage D did not plate or propagate on the Providencia or Serratia strains carrying IncD plasmids despite the fact that the strains possessed intact transfer systems (see Results). Similar situations have been repeatedly encountered (Bradley et al., $1981 b$, c; Coetzee et al., 1979). Hua et al. (1981) investigated a Caulobacter system where 
Table 3. Host range of phage $D$ compared to that of phages $M S 2, f d, F_{0} l a c$ and $J$

Dilutions of phage suspensions (about $1 \times 10^{9}$ p.f.u. $\mathrm{ml}^{-1}$ ) were dropped on lawns of organisms contained in top-layer agar. Plates were incubated at $26^{\circ} \mathrm{C}$ for $18 \mathrm{~h}$. Phage propagation was assessed as referred to in Methods.

\begin{tabular}{|c|c|c|c|c|c|c|c|}
\hline \multirow[b]{2}{*}{ Host } & \multirow{2}{*}{$\begin{array}{l}\text { Plasmid } \\
\text { Inc group }\end{array}$} & \multicolumn{4}{|c|}{ Phage action* } & & \multirow[b]{2}{*}{ Plasmid reference } \\
\hline & & D & MS2 & $\mathrm{fd}$ & $\mathrm{F}_{0} l a c$ & $\mathbf{J}$ & \\
\hline J62-1(RA1) & $\mathrm{C}$ & - & - & - & - & + & Jacob et al. (1977) \\
\hline J62-1(PHH1184) & $\mathrm{C}$ & - & - & - & - & + & Datta et al. (1980) \\
\hline $\mathrm{J} 62-1(\mathrm{R} 711 \mathrm{~b})$ & $\mathrm{D}$ & + & - & + & - & + & \\
\hline $\mathrm{J} 62-1(\mathrm{R} 840)$ & $\mathrm{D}$ & + & - & + & - & + & Hedges (1974); Bradley et al. (1982) \\
\hline J53(R687) & $\mathrm{D}$ & + & - & + & - & + & \\
\hline J53(R778b) & $\mathrm{D}$ & + & - & + & - & + & \\
\hline LT2trpA8-1(R687) & D & $+\dagger$ & - & - & - & - & \\
\hline LT2trpA8-1(R840) & D & $+\dagger$ & - & - & - & - & \\
\hline SM89-1(R711b) & D & $-(-)$ & - & - & - & - & \\
\hline G147(R687) & D & $+\dagger$ & - & - & - & - & \\
\hline G147(R711b) & D & $+\dagger$ & - & - & - & - & \\
\hline G147(R778b) & D & $+t$ & - & - & - & - & - Hedges (1974); Bradley et al. (1972) \\
\hline $2815 n a l-r(\mathrm{R} 778 \mathrm{~b})$ & D & $+\dagger$ & - & - & - & - & Heages (19/4); Bradley et al. (19/2) \\
\hline $2815-2(\mathrm{R} 840)$ & D & $+\dagger$ & - & - & - & - & \\
\hline P29-2(R687) & D & $-(-)$ & - & - & - & - & \\
\hline P29-2(R711b) & D & $-(-)$ & - & - & - & - & \\
\hline P29-2(R778b) & D & $-(-)$ & - & - & - & - & \\
\hline P29nal-r(R840) & $\mathrm{D}$ & $-(-)$ & - & - & - & - & \\
\hline NTTC 9297-1(R687) & D & $-(-)$ & - & - & - & - & \\
\hline NCTC $9297-1(R 711 b)$ & $\mathrm{D}$ & $-(-)$ & - & - & - & - & \\
\hline NCTC $9297-1(\mathrm{R} 840)$ & $\mathrm{D}$ & $-(-)$ & - & - & - & - & \\
\hline J53-2(R386) & FI & - & + & + & - & - & Dennison (1972) \\
\hline J53-2(R1drd19) & FII & - & + & + & - & - & Jacob et al. (1977) \\
\hline J53(ColB-K 98) & FIII & - & + & + & - & - & Frydman \& Meynell (1969) \\
\hline J62-1(R124) & FIV & - & + & + & - & - & Hedges \& Datta (1972) \\
\hline J62-1(EDP208) & $\mathrm{F}_{0} l a c$ & - & - & + & + & - & Bradley \& Meynell (1978) \\
\hline J62-1(R997) & $\mathbf{J}$ & - & - & - & - & + & Matthew et al. (1979); Bradley (1980) \\
\hline
\end{tabular}

* + , Plaque formation; - , no visible action; $(-)$, no titre increase in two propagation experiments.

$\dagger$ Plaques more turbid and irregular in outline.

the pili coded for by the IncP plasmid RP1 were functionally changed in the latter host. The pili still provided adequate conjugative functions, but now lacked receptor sites for phage PRR1. The selectivity of phage fd for $E$. coli hosts (Table 3 ) also has a precedent: phage fl which resembles the former phage (Denhardt, 1975; Hill \& Petersen, 1982) only plates on E. coli strains carrying IncF plasmids and not on strains of $S$. typhimurium with the same plasmids (Loeb, 1960). Nevetheless, the fact that the Providencia strains carrying the plasmids were not lysed by phage $\mathrm{D}$ is surprising considering the derivation of these plasmids (see above).

No serological relationship could be demonstrated between phages D and MS2 (see Results) despite the normally fleeting association detected by Bradley \& Meynell (1978) between the latter phage and IncD plasmid-coded pili. A possible explanation could be that whereas formalin-fixed preparations show phage MS2 adsorbed uniformly along the length of the shafts of R711b pili, phage D only adsorbed to the very distal sides of the shafts. These sites could differ antigenically from the rest of the pilus shaft.

Apart from the particular adsorption site on pili (see Results), phage D differs from most other RNA-containing phages (Fiers, 1979) in two further respects: chloroform sensitivity of the virions and the temperature sensitivity of plaque formation (see Results). The former property is shared with phages $\mathrm{M}$ and pilH $\alpha$ (Coetzee et al., 1983, 1985). The latter feature was considered a unique property of phage pilH $\alpha$ until the present phage was isolated. The restricted development temperature of these wild phages has not been investigated further but certainly justified the lower temperature used for phage isolation. 


\section{REFERENCES}

Ackermann, H.-W., Audurier, A., Berthiaume, L., Jones, L. A., Mayo, J. A. \& Vidaver, A. K. (1978). Guidelines for bacteriophage characterization. $A d$ vances in Virus Research 23, 1-24.

ADAMs, M. H. (1950). Methods of study of bacterial viruses. Methods in Medical Research 2, 1-73.

Bachmann, B. J. (1972). Pedigrees of some mutant strains of Escherichia coli K-12. Bacteriological Reviews, 36, 525-557.

BRADLEY, D. E. (1967). Ultrastructure of bacteriophages and bacteriocins. Bacteriological Reviews 31, $230-314$.

Bradley, D. E. (1977). Characterization of pili determined by drug resistance plasmids $\mathrm{R} 711 \mathrm{~b}$ and R778b. Journal of General Microbiology 102, 349363.

BRADLEY, D. E. (1980). Morphological and serological relationships of conjugative pili. Plasmid 4, 155-169.

Bradley, D. E. \& MEYNELl, E. (1978). Serological characteristics of pili determined by the plasmids $\mathrm{R} 711 \mathrm{~b}$ and $\mathrm{F}_{0}$ lac. Journal of General Microbiology 108, 141-149.

Bradley, D. E., Taylor, D. E. \& Cohen, D. R. (1980). Specification of surface mating systems among conjugative drug resistance plasmids in Escherichia coli K-12. Journal of Bacteriology 143, 1466-1470.

Bradley, D. E., Coetzee, J. N., Bothma, T. \& Hedges, R. W. $(1981 a)$. Phage $\mathrm{F}_{0}$ lac: an $\mathrm{F}_{0}$ lac plasmid-dependent bacteriophage. Journal of General Microbiology 126, 405-411.

Bradley, D. E., Coetzee, J. N., Bothma, T. \& Hedges, R. W. (1981b). Phage X: a plasmiddependent, broad host range, filamentous bacterial virus. Journal of General Microbiology 126, 389 396.

Bradley, D. E., Coetzee, J. N., Bothma, T. \& Hedges, R. W. (1981c). Phage $\mathrm{t}$ : a group T plasmiddependent bacteriophage. Journal of General Microbiology 126, 397-403.

Bradley, D. E., Sirgel, F. A., Coetzee, J. N., Hedges, R. W. \& Coetzee, W. F. (1982). Phages C2 and $\mathbf{J}$ : IncC and IncJ plasmid-dependent phages, respectively. Journal of General Microbiology 128, 2485-2498.

Clowes, R. C. \& HaYes, W. (1968). Experiments in Microbial Genetics, p. 189. Oxford \& Edinburgh: Blackwell Scientific Publications.

Coetzee, J. N. (1963). Lysogeny in Providence strains and the host-range of Providence bacteriophage. Natue, London 197, 515-516.

Coetzee, J. N. (1966). Transduction in Proteus morganii. Nature, London 210, 220.

Coetzee, J. N. \& Kruger, A. M. (1980). Genetic recombination between Proteus mirabilis and Providencia alcalifaciens. Journal of General Microbiology 120, 57-66.

Coetzee, J. N., Smit, J. A. \& Prozesky, O. W. (1966). Properties of Providence and Proteus morganii transducing phages. Journal of General Microbiology 44, 167-176.

Coetzee, J. N., Datta, N. \& Hedges, R. W. (1972). R factors from Proteus rettgeri. Journal of General Microbiology 72, 543-552.

Coetzee, J. N., Lecatsas, G., Coetzee, W. F. \&
Hedges, R. W. (1979). Properties of R plasmid R772 and the corresponding pilus-specific phage PR772. Journal of General Microbiology 110, 263-273.

Coetzee, J. N., Bradley, D. E. \& Hedges, R. W. (1982). Phages $I \alpha$ and $I_{2}-2$ : IncI plasmid-dependent bacteriophages. Journal of General Microbiology 128 , 2797-2804.

Coetzee, J. N., Bradley, D. E., Hedges, R. W., Fleming, J. \& LeCATSAS, G. (1983). Bacteriophage $\mathbf{M}$ : an incompatibility group $\mathbf{M}$ plasmid-specific phage. Journal of General Microbiology 129, 22712276.

Coetzee, J. N., Bradley, D. E., Fleming, J., du Toit, L., Hughes, V. M. \& Hedges, R. W. (1985). Phage pilH $\alpha$ : a phage which adsorbs to IncHI and IncHII plasmid-coded pili. Journal of General Microbiology 131, $1115-1121$

DatTa, N. (1977). Classification of plasmids as an aid to understanding their epidemiology and evolution. Journal of Antimicrobial Chemotherapy 3 (Supplement C) $19-23$.

DatTA, N. (1979). Plasmid classification: incompatibility grouping. In Plasmids of Medical, Environmental and Commercial Importance, pp. 3-12. Edited by K. N. Timmis \& A. Pühler. Amsterdam: Elsevier/ North-Holland Biomedical Press.

Datta, N., Dacey, S., Hughes, V., Knight, S., Richards, H., Williams, G., Casewell, M. \& Shannon, K. P. (1980). Distribution of genes for trimethoprim and gentamicin resistance in bacteria and their plasmids in a general hospital. Journal of General Microbiology 118, 495-508.

Davis, J. E., Strauss, H. J. \& Sinsheimer, R. L. (1961). Bacteriophage MS2: another RNA phage. Science 134, 1427.

DenhardT, D. T. (1975). The single-stranded DNA phages. CRC Critical Reviews in Microbiology 4, 161223.

DENNISON, S. (1972). A naturally occurring R factor derepressed for pilus synthesis, belonging to the same compatibility group as the sex factor $F$ of Escherichia coli K12. Journal of Bacteriology 109, 416-422.

FIERS, W. (1979). Structure and function of RNA bacteriophages. In Comprehensive Virology 13, pp. 69-204. Edited by C. Fraenkel-Conrat \& A. M. Wagner. New York: Plenum.

Frydman, A. \& Meynell, E. (1969). Interactions between derepressed F-like $\mathrm{R}$ factors and wild type colicin B factors: superinfection immunity and repressor susceptibility. Genetical Research 14, 315332.

Gale, E. F., Cundliffe, E., Reynolds, P. E., RICHMOND, M. H. \& WARING, M. J. (1972). The Molecular Basis of Antibiotic Action, pp. 9-23. London: John Wiley \& Sons.

Hedges, R. W. (1974). R factors from Providence. Journal of General Microbiology 81, 171-181.

Hedges, R. W. \& DatTa, N. (1972). R124, an $f^{+}$R factor of a new compatibility class. Journal of General Microbiology 71, 403-405.

Hershey, A. D., Kalmanson, G. \& BronfenbrenNER, J. (1943). Quantitative methods in the study of the phage-antiphage reaction. Journal of Immunology 46, 267-276. 
Hill, D. R. \& Petersen, G. B. (1982). Nucleotide sequence of bacteriophage fl DNA. Journal of Virology 44, 32-46.

Hua, T.-C., Scholl, D. R. \& Jollick, J. D. (1981). Functional modification of the plasmid RPl-specified pilus by Caulobacter vibrioides. Journal of General Microbiology 124, 119-128.

Jacob, A. E., Shapiro, J. A., Yamamoto, L., Smith, D. I., Cohen, S. N. \& Berg, D. (1977). Plasmids studied in Escherichia coli and other enteric bacteria. In DNA Insertion Elements, Plasmids and Episomes, pp. 607-638. Edited by A. I. Bukhari, J. A. Shapiro \& S. L. Adhya. Cold Spring Harbor, New York: Cold Spring Harbor Laboratory.

LOEB, T. (1960). Isolation of a bacteriophage specific for the $\mathrm{F}^{+}$and $\mathrm{Hfr}$ mating types of Escherichia coli $\mathrm{K}$ 12. Science 131, 932-933.

Marvin, D. A. \& HoffMann-Berling, H. (1963). Physical and chemical properties of two new small bacteriophages. Nature, London 197, 517-518.

Matthew, M., Hedges, R. W. \& Smith, J. T. (1979). Types of $\beta$-lactamase determined by plasmids in Gram-negative bacteria. Journal of Bacteriology 138 , 657-662.
Meynell, E. (1978). Experiments with sex pili: an investigation of the characters and function of F-like and I-like sex pili based on their reactions with antibody and phage. In Pili, pp. 207-233. Edited by D. E. Bradley, E. Raizen, P. Fives-Taylor \& J. Ou. Washington, DC: International Conferences on Pili. Meynell, G. G. \& Lawn, A. M. (1968). Filamentous phages specific for the I sex factor. Nature, London 217, 1184-1186.

Meynell, E., Meynell, G. G. \& Datta, N. (1968) Phylogenetic relationships of drug-resistance factors and other transmissible bacterial plasmids. Bacteriological Reviews 32, 55-83.

Sirgel, F. A., Coetzee, J. N., Hedges, R. W. \& LeCATSAS, G. (1981). Phage C-1: an IncC group plasmid-specific phage. Journal of General Microbiology 122, 155-160.

Watanabe, M. \& August, J. T. (1967). Methods for selecting RNA bacteriophage. Methods in Virology 3, 337-350.

Yamamoto, K. R., Alberts, B. M., Benzinger, R., LAWHORNE, L. \& TREIBER, G. (1970). Rapid bactiophage sedimentation in the presence of polyethylene glycol and its application to large-scale virus purification. Virology 40, 734-744. 